\title{
Petrofacies Evolution of Bayana Basin Sandstones of Mesoproterozoic Delhi Supergroup, Bharatpur District, Rajasthan, Northwestern India
}

\author{
Abul Hasnat Masood Ahmad ${ }^{1}$, Chayanika Saikia², Syed Mohammad Wasim ${ }^{3}$ \\ ${ }^{1}$ Department of Geology, Aligarh Muslim University, Aligarh, India \\ ${ }^{2}$ Directorate General of Hydrocarbons (DGH), Delhi, India \\ ${ }^{3}$ Department of Geology, Aligarh Muslim University, Aligarh, India \\ Email: ahmahmad2004@yahoo.com, chayanika.saikia08@gmail.com,w4wasimamuii@gmail.com
}

Received June 2, 2012; revised June 29, 2012; accepted July 27, 2012

\begin{abstract}
The paper embodies results of petrofacies, detrital mineralogy and textural aspects of Bayana Basin sandstones of the Delhi Supergroup. These sandstones consisting of various types of quartz, feldspar, mica, rock fragments and heavy minerals are medium to fine grained and moderately well sorted. These sediments are generally subangular to subrounded with low sphericity. Various factors responsible for modification of the original detrital composition of the sandstones have been critically examined. Distance of transport is one of the factors which control the composition at the time of deposition. The plots of petrofacies in QtñFñL, QmñFñLt, QpñLvñLs and QmñPñK ternary diagrams suggest mainly basement uplift source (Craton interior) in a rifted continental margin basin setting, which has also received sediment input from recycled orogen provenance.
\end{abstract}

Keywords: Petrofacies Evolution; Bayana Basin; Mesoproterozoic; Bharatpur District (India)

\section{Introduction}

The relationship between plate tectonics and sandstone composition has been the subject of intensive research and discussion over the last three decades. Many studies have pointed to an intimate relationship between detrital sand composition and tectonic setting [1-7].

However, the correlation between tectonic setting and sandstone petrofacies may not always be valid, due to modification of sandstone compositions by recycling, transport and post depositional processes. The most notable modifying agents are intense chemical weathering under a tropical humid climate and low relief [8-10], differential abrasion during pre-depositional and preburial transport [12,13] and diagenesis [14]. Sediment recycling [11], mixing of detritus derived from two sources, temporal changes in tectonic style [15], and long sediment transport across the mother plate to tectonically alien Basins also hinder the identification of generic tectonic setting and provenance. This paper attempts to the study petrofacies of the Bayana Basin sandstones of Bharatpur District in relation to depositional environments. The petrofacies of this Basin is interpreted in the light of known evolution of the Aravalli Craton, Keeping

${ }^{*}$ Corresponding author. in view the various modifying factors that control and influence the original detrital compositions.

\section{Geological Setting}

The studied Bayana Basin is composed of a $3000 \mathrm{~m}$ thick sequence of conglomerate, sandstone, shale, basal mafic volcanic flows and valcanoclastics. The Basin has been subjected to a three-tier classification, mainly on the basis of two unconformities. The infillings of this Basin are represented by metasedimentary rocks and metavolcanics belonging to Mesoproterozoic Delhi Supergroup which has a faulted contact with Pre-Delhi rocks along its south-eastern fringe (Figures 1 and 2). Stratigraphically, the area is divisible into eight Formations that are form the oldest to youngest, the Nithar, Jahaj-Govindpura Volcanics, Jogipura, Badalgarh, Bayana, Damdama, (Alwar group), Kushalgarh and Weir (Ajabgarh group) [16].

\section{Facies Analysis}

A total of fourteen lithofacies from seven Mesoprotozoic Formations of the Bayana Basin have been recognized on the basis of lithology and sedimentary structures. Four distinct facies assemblages have been identified based on the association of lithofacies, textural characteristics, 


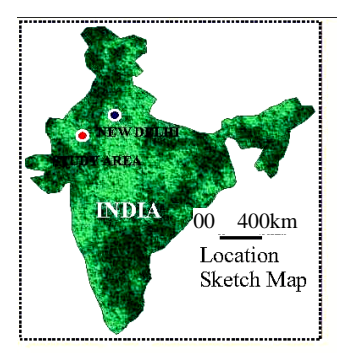

$\uparrow_{\mathrm{N}}$

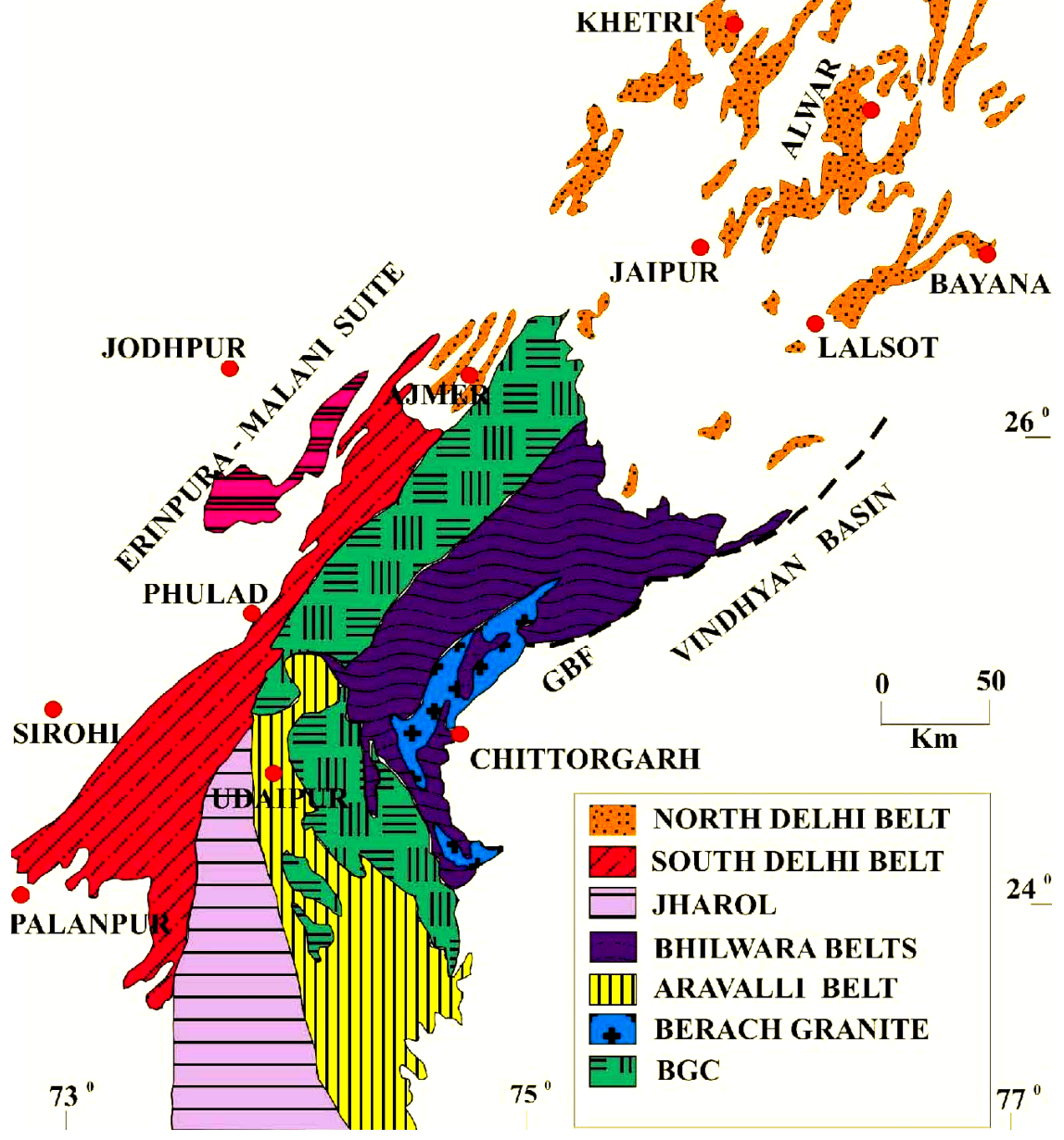

Figure 1. Simplified tectonic map of Aravalli Mountain Range, NW Indian Shied (after Gupta et al., 1980).

sedimentary structures and environment of deposition. The four main facies assemblage ascribed to tidally in fluenced fluvial deposition (Facies Association A), tidal flat deposition (Facies Association B), tidal channel deposition (Facies Association $\mathrm{C}$ ) and wave \& storm dominated shoreface deposition (Facies Association D). These contrasting palaeoenvironmental settings suggest sedimentation at a Basin margin. Sediments were deposited in fluvial as well as shallow marine environments. Fluvial deposits are limited, but tidal deposits are regionally extensive. Sediments accumulated in a tide dominated estuary, on an intertidal flat, in tidal channel, in wave dominated shallow water environment, as well as in a storm dominated upper to lower shoreface. Evidence of alternate episodes of transgression and regression is well documented in the study area [17]. Also, primary sedimentary structures are mostly well preserved. Although interpretation of tidal regime in terms of a macro, meso or micro-tidal range is not easy, the sandstones show many features which are indicative of macro-tidal environment. The $85 \mathrm{~m}$ thick outcrop exposed at the Bayana locality represents fluvial deposits modified by tidal processes in tidal estuary settings, indicating that the coastline was macro tidal ( $>4 \mathrm{~m}$ ), at least for some periods. Other feature suggestive of macro-tidal are abundant parallel laminated sandstone facies, occasional occurrences of herring-bone cross-bedding, and wavy bedding as well as interbedded sandstone-shale sequences. 


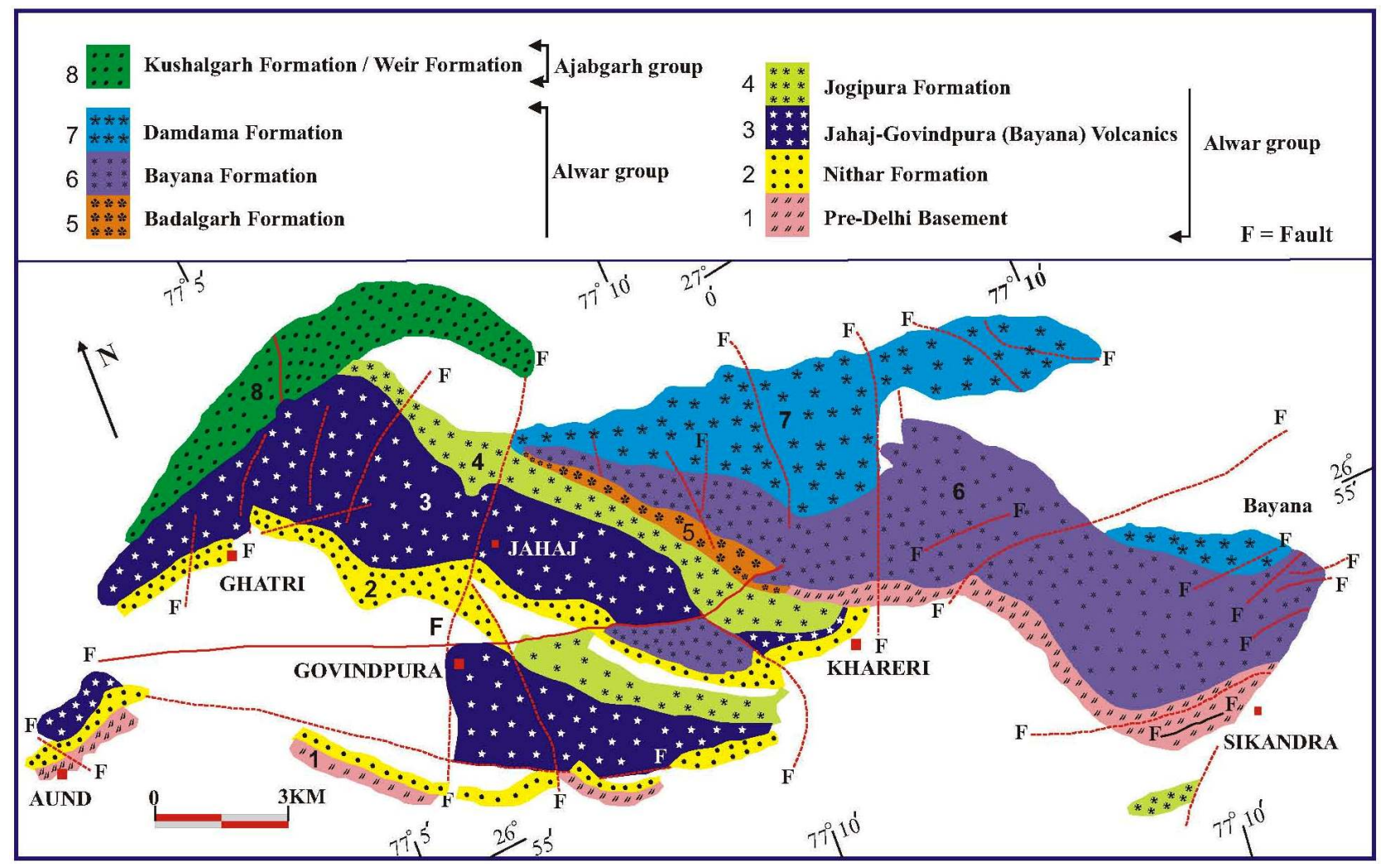

Figure 2. Geological map of Bayana Basin (after Singh, 1982).

The Presence of hummocky cross-bedded sandstones suggests that the shoreface sediments of the Bayana Formation are storm-dominated. Overall, studieds suggest that the Bayana Basin sediments supplied during episodic transgressive and regressive phases were modified by tidal processes and later by wave and stormdominated processes in a shallow marine environment (Figure 3).

\section{Petrography}

The textural and compositional study is based on 106 samples. The samples were selected in such a way that lateral and vertical variations within all formations are uniformly controlled. For quantitative analysis about 300 400 points per thin section were counted for determining the modal composition of rocks under investigation. The graphic mean $(\mathrm{Mz})$ of various samples range from 1.03 to 3.95 , average 1.97 and most of the samples are medium grained. Inclusive graphic standard deviation $(\sigma \mathrm{I})$ values ranges from 0.41 to 1.29 , average 0.63 . The sandstones are mostly moderately well sorted to moderately sorted. The mean roundness of the individual samples ranges from 0.26 to 0.46 , average 0.35 ; in most samples the majority of the grains are subangular to sub rounded. The distribution of roundness in individual samples is invariably unimodal with subrounded as the modal class.
The mean grain sphericity values range from 0.36 to 0.68 , average 0.54 . The studied sandstones are texturally submature (Table 1).

The sandstones are mainly composed of several varieties of quartz followed by feldspars, rock fragments, mica and heavy minerals. The average detrital mineralogy in the studied sandstones includes monocrystalline quartz (84.69\%), polycrystalline recrystallized metamorphic quartz (4.18\%), stretched metamorphic quartz (2.36\%), feldspar (3.98\%), rock fragments (3.43\%), mica (1\%), and heavy minerals $(0.27 \%)$ (Table 2$)$. The individual Formation wise studies indicates that most of the samples fall in quartzarenite field, followed by sublitharenite, feldspathic litharenite, arkose and subarkose fields.

\section{Factor Controlling Detrital Mineralogy}

Distance of transport is one of the factors which control the composition at the time of deposition. The processes of mechanical breakdown, abrasion, hydrodynamic sorting during transportation etc. result in compositional maturation of detrital in to more quartzose detrital mode. The detrital grains of Bayana Basin sandstones are in the sand size range and derived from only $100 \mathrm{~km}$ distance from Dausa uplift and Rajputana Craton [17]. Due to presence of small amount of feldspar and rock fragments in the studied sandstone, prolonged reworking and pre- 


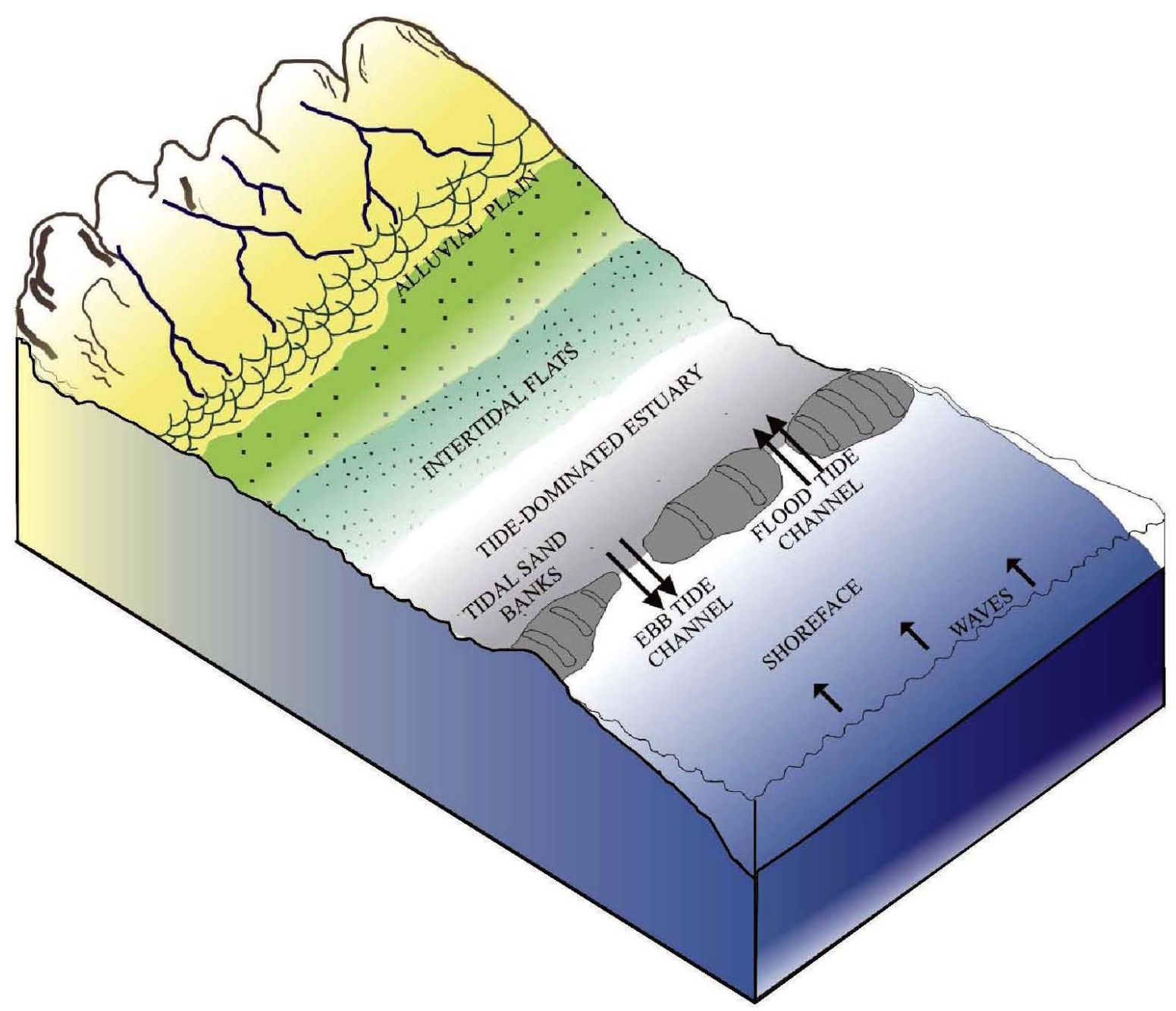

Figure 3. Diagrammatic representation of depositional environments of Bayana Basin.

Table 1. Textural parameters of Bayana Basin sandstones, Delhi Supregroup, Rajasthan.

\begin{tabular}{|c|c|c|c|c|c|c|c|c|c|c|c|c|c|c|}
\hline & \multicolumn{2}{|c|}{$\begin{array}{c}\text { Nithar Formation } \\
\text { (Facies Association } \\
\text { A \& B) } \\
\text { (No. of Samples 10) }\end{array}$} & \multicolumn{2}{|c|}{$\begin{array}{c}\text { Jahaj-Govindpura } \\
\text { Formation } \\
\text { (Facies Association } \\
\text { B) } \\
\text { (No. of Samples 19) }\end{array}$} & \multicolumn{2}{|c|}{$\begin{array}{c}\text { Jogipura Formation } \\
\text { (Facies Association } \\
\text { A, B \& C) } \\
\text { (No. of Samples 11) }\end{array}$} & \multicolumn{2}{|c|}{$\begin{array}{c}\text { Badalgarh } \\
\text { Formation } \\
\text { (Facies Association } \\
\text { A \& B) } \\
\text { (No. of Samples 13) }\end{array}$} & \multicolumn{2}{|c|}{$\begin{array}{c}\text { Bayana Formation } \\
\text { (Facies Association } \\
\text { A \& C) } \\
\text { (No. of Samples 32) }\end{array}$} & \multicolumn{2}{|c|}{$\begin{array}{c}\text { Damdama } \\
\text { Formation } \\
\text { (Facies Association } \\
\text { A, C \& D) } \\
\text { (No. of Samples 13) }\end{array}$} & \multicolumn{2}{|c|}{$\begin{array}{c}\text { Weir Formation } \\
\text { (Facies Association } \\
\text { D) } \\
\text { (No. of Samples 8) }\end{array}$} \\
\hline & Range & Average & Range & Average & Range & Average & Range & Average & Range & Average & Range & Average & Range & Average \\
\hline $\mathrm{MZ}$ & $2.05-2.7$ & 2.3 & $2.05-3.95$ & 2.2 & $1.13-3.11$ & 2.4 & $1.63-1.83$ & 1.78 & $1.13-2.39$ & 1.55 & $1.03-2.29$ & 1.72 & $1.41-2.25$ & 1.87 \\
\hline$\sigma \mathrm{I}$ & $0.40-0.82$ & 0.64 & $4.48-1.29$ & 0.64 & $0.43-0.92$ & 0.72 & $0.43-0.63$ & 0.51 & $0.48-0.77$ & 0.64 & $0.58-0.80$ & 0.73 & $0.48-0.69$ & 0.56 \\
\hline MR & $0.35-0.46$ & 0.37 & $0.27-0.38$ & 0.35 & $0.34-0.40$ & 0.36 & $0.28-0.36$ & 0.34 & $0.26-0.36$ & 0.33 & $0.34-0.37$ & 0.36 & $0.34-0.37$ & 0.35 \\
\hline MS & $0.36-0.50$ & 0.41 & $0.55-0.62$ & 0.59 & $0.49-0.60$ & 0.55 & $0.47-0.55$ & 0.50 & $0.43-0.58$ & 0.49 & $0.51-0.68$ & 0.61 & $0.53-0.62$ & 0.56 \\
\hline $\mathrm{TM}$ & SM & SM & SM & SM & SM & SM & SM & SM & SM & SM & SM & SM & SM & SM \\
\hline
\end{tabular}

MZ = Graphic mean, $\sigma \mathrm{I}=$ Inclusive Graphic Standard deviation, MR = Mean roundness, MS = Mean sphericity, TM = Textural maturity, SM = Submature.

sence of high gradient stream is quite likely within the basin. However, this premise doesn't stand to scrutiny because rock fragment that could have been destroyed more easily are more common then feldspars.
The presence of weathered feldspars grains as well as oversize pores indicates dissolution of detrital grains in the studied sandstones. The replacement of quarts grains by iron in some thin section suggests slight modification 


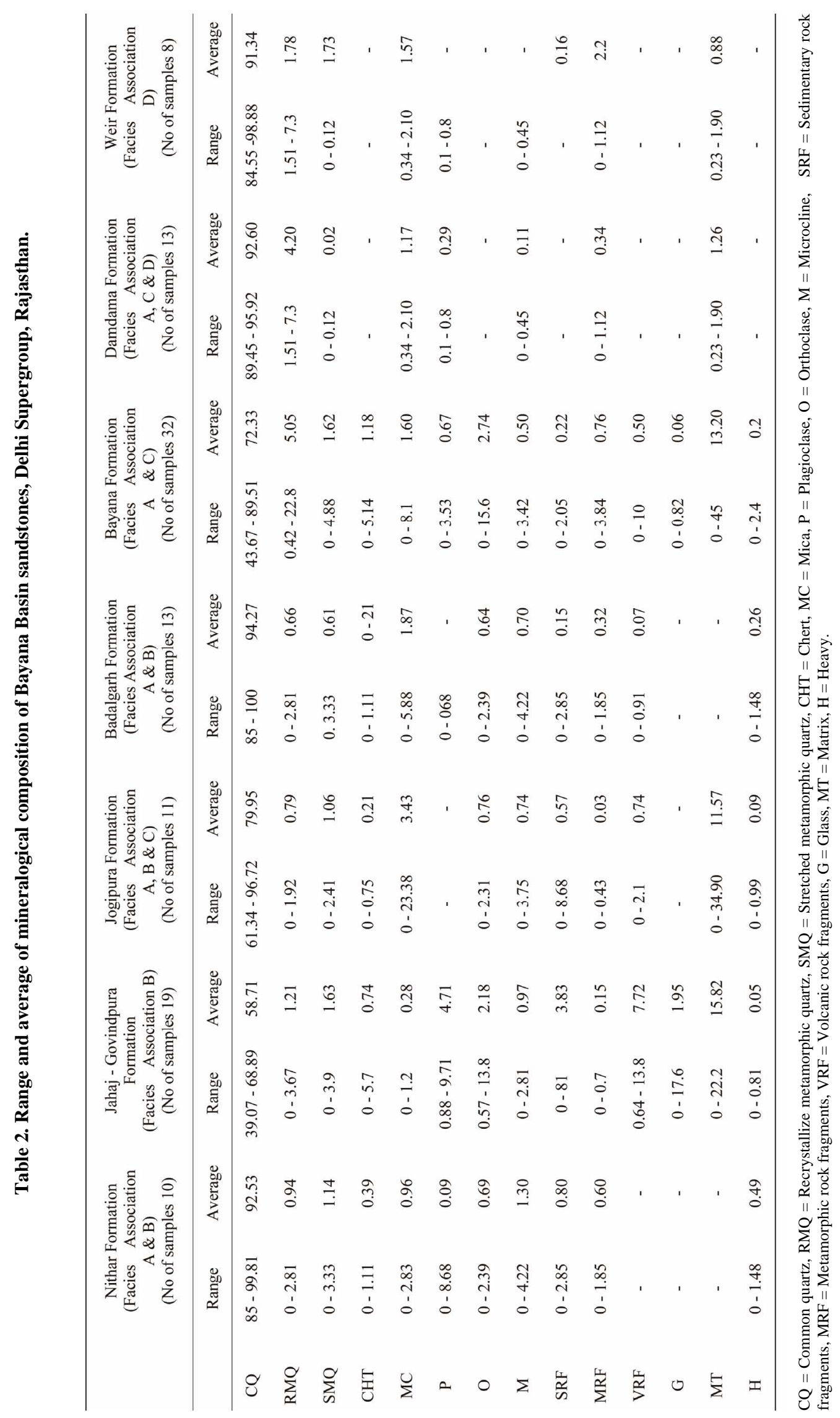


of the composition of the sandstone. The study of grain contacts of the Bayana Basin sandstones indicates that the sandstones are subjected to compaction during burial and their original texture and fabric slightly modified by the process of composition.

\section{Tectono-Provenance}

1) Four triangular diagrams, QtñFñL, QmñFñLt, QpñLvñLs and QmñPñK were used in this study (Table 3). Both QtñFñL and QmñFñLt Plots show full grain populations, but with different emphasis. In the QtñFñL plot, where all quartz grains are plotted together, the emphasis is on grain stability, and thus on weathering, provenance relief, and transport mechanism as well as source rocks; while in QmñFñLt, where all lithic frag- ments are plotted together, the emphasis is shifted to- wards the grain size of source rock, because fine-grained rocks yield more lithic fragments in the sand size range. The QpñLvñLs and QmñPñK plots show only partial grain populations but reveal the character of polycrystalline and monocrystalline components of the framework, respectively.

2) The study revealed that monocrystalline quartz (Qm) is the dominant mineral in the sandstones. Its percentages range from $58.51 \%$ to $96.7 \%$ (av. 84.69\%. Polycrystalline quartz (Qp) includes both recrystallized quartz and stretched metaquartz: the former ranges from $0.3 \%$ to $5.54 \%$ (av. $4.18 \%$ ) and latter ranges from $0.1 \%$ to $2.1 \%$ (av. 2.36\%) of the detrital fraction. The feldspars (F) occur in small amounts in the sandstones (3.98\%). Rock fragments include shale, siltstone, chert, schist, gneiss, quartzite and mafic volcanics lithic; their percentages range from $0.36 \%$ to $10.16 \%$ (av. $4.18 \%$ ).

3) Most of the samples of the Bayana Basin sandstones lay in the continental block provenance field on the QtñFñL (Figure 4(a)) plot, suggesting contribution from the craton interior with basement uplift. The remaining of the samples fall in the recycled orogen provenance which suggests their derivation from metasedimentary and sedimentary rocks that were originally deposited along former passive continental margins $[6,18]$. The QmñFñLt plot (Figure 4(b)) shows that the samples fall in continental block provenance with little contribution from the recycled orogen provenance. In the QmñPñK diagram (Figure 4(d)); the data lie in the continental block provenance reflecting maturity of the sediments and stability of the source area. The QpñLvñLs plot (Figure 4(c)), which is based on rock fragments population reveals the polymineralic nature of the source region and gives a more resolved picture about the tectonic elements.

4) The plots of Bayana Basin sandstones on QtñFñL and QmñFñLt diagrams suggest that the detritus of the sandstones were derived from the granite-gneisses ex- humed in the craton interior and medium to high grade metamorphosed supracrustals forming recycled orogen provenance (Metamorphic quartz, muscovite \& biotite, plagioclase, epidote, magnetite). This suggests derivation of the sandstone from stable parts of the craton, with perhaps an equal contribution from a recycled orogen. In the QpñLvñLs plot, the sample mostly plot in the mixed orogenic provenance with contributions from both an arc orogen source and a fold thrust belt source. The QmñPñK diagram suggests the maturity and stability of the source region. This may have stemmed from a very long period of tectonic quiescence and mature geomorphology of the source areas. The composition and maturity of sands is primarily controlled by the source rock and tectonics, but secondary processes, such as climate and weathering and depositional reworking and abrasion, acting singly or in combinations, tends to destroy the labile constituents and produce quartz rich sand. Intense weathering under warm and humid climates and long residence time in soils may destroy feldspars and other labile constituents resulting in high degree of compositional maturity of sediments.

5) The relative abundance of monocrystalline quartz to that of polycrystalline quartz reflects the maturity of the sediments, because polycrystalline quartz is eliminated by recycling and disintegrates in the zone of weathering as does strained quartz [9]. The sandstones have considerably high percentages of monocrystaline quartz (84.68\%) as compared to polycrystalline quartz (15.32\%), which indicates removal of polycrystalline quartz by weathering and recycling. The abundance of feldspar also serves as a guide to determine the maturity index since much of the feldspar is destroyed by weathering where relief is low and rainfall high, the occurrence of weathered and fresh feldspars together may indicates derivation from two different sources or deep erosion.

6) Considering the regional perspective, Mesoproterozoic Delhi Supergroup deposits are wide spread in outcrop and the subsurface throughout the Aravalli $\tilde{n}$ Delhi mountain belt. The Delhi fold Belt consists of highly folded and deformed rocks exhibiting polyphase metamorphism of deep water to platformal sediments. Generally, the mountain belts represent regions where oceans might have opened and closed, and they are the products of continental collision [19]. These mountains had been eroded and had low relief, typical of tectonically stable cratonic areas. Plate tectonic processes of continental collision, suturing and consumption of the crust at plate margins by thrusting or under plating led to crustal thickening and formation of orogenic belts in Phanerozoic and Proterozoic times. Knowledge of crustal structural and tectonics of the ancient collision belts can lead to better understanding of the mechanism of crustal growth processes, provided, later tectonic activity has not disturbed the original structure. Rift opening of the Delhi 


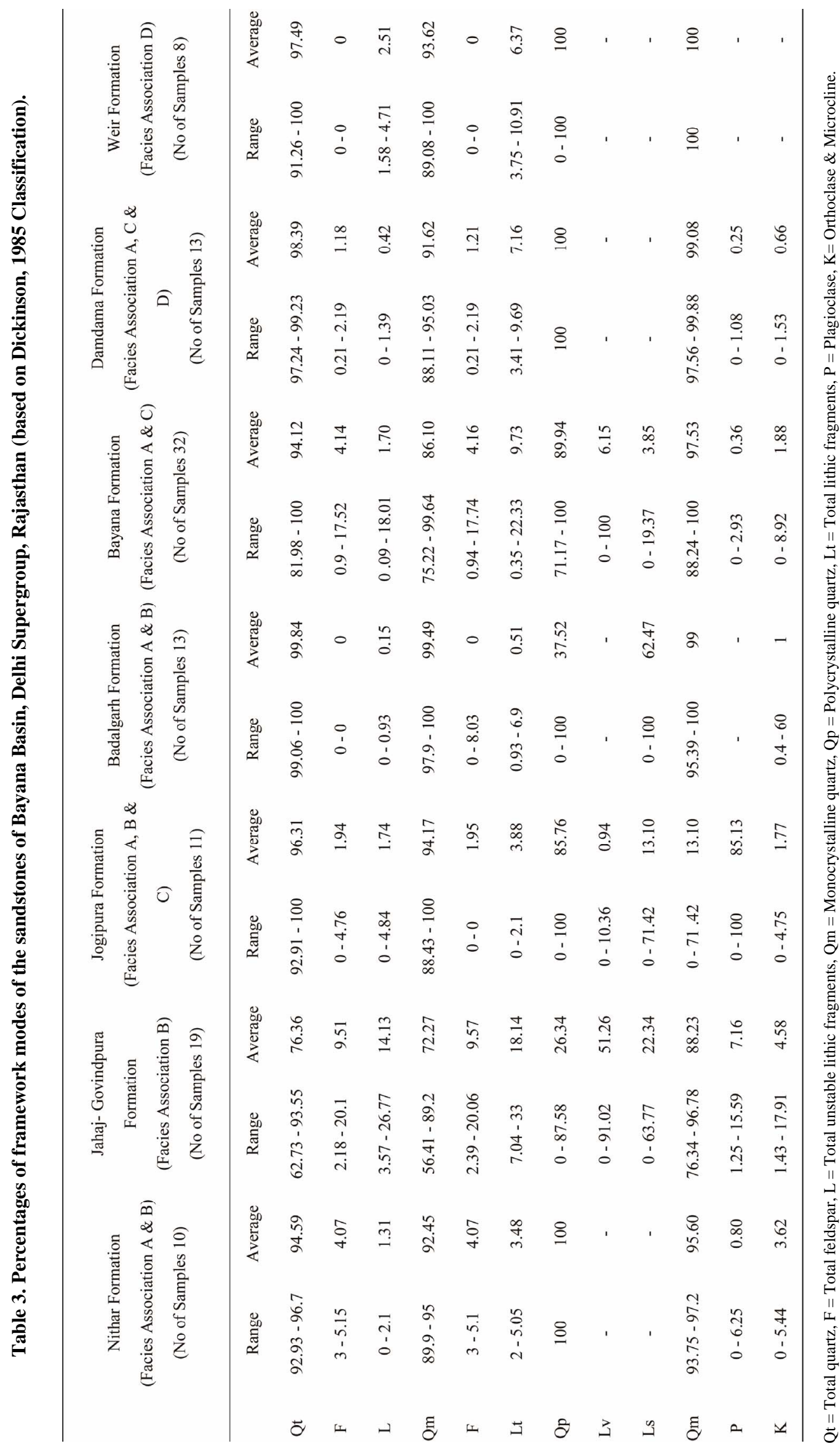




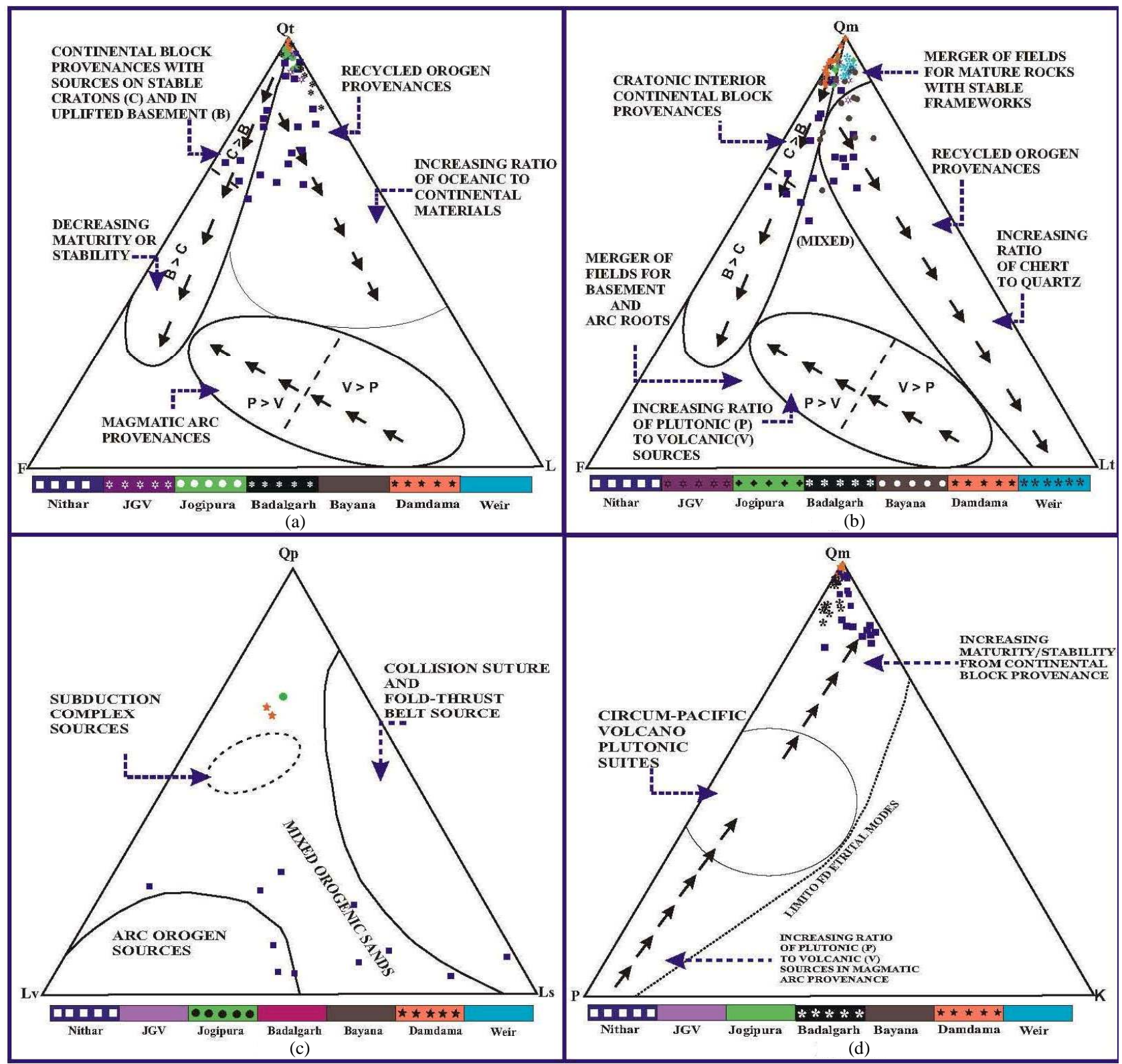

Figure 4. (a)-(d) Plots of the Bayana Basin sandstones, according to Dickinson (1985).

Basin is now considered as well established [17]. The cratonic sediments were deposited in a shelf sea during the initial stages of Basin opening. Delhi Supergroup rocks were deposited in either fluvial or various coastal environments. In its northeastern part, the Delhi Basin exhibits several depositories that are small in size and are separated from each other by uplands. A series of north to northeast trending synsedimentary faults have been recognized [17], which bound the depositories are intrabasinal faults. A total of 235 measurements of azimuth of cross-bedding (both trough and tabular) were collected from 10 localities belonging to 7 Formations. Paleocurrent data in the study area show that sediment dispersal was multidirectional. Maximum sediments derived from the Banded Gneissic Complex (BGC) of the Aravalli Block (AB) and small quantities of sediments derived from the Bundelkhand Granite ñ Gneiss (BGG) of the Bundelkhand Block (BB) of the North Indian Craton (NIC) (Figure 5). It may be inferred that fluvial deposits were formed in a low-lying stable continental area during regression while fluvial and shallow marine deposits were formed in the shelf margin during transgression [20]. In view of this, it can be considered that sediments in and around the Banded Gneissic Complex and the Bundelkhand Granite ñ Gneiss were deposited on a lowlying landmass that form a stable continental shelf.

7) On the basis of geochemical data, the provenance analysis suggests that the basin received debris from dif- 


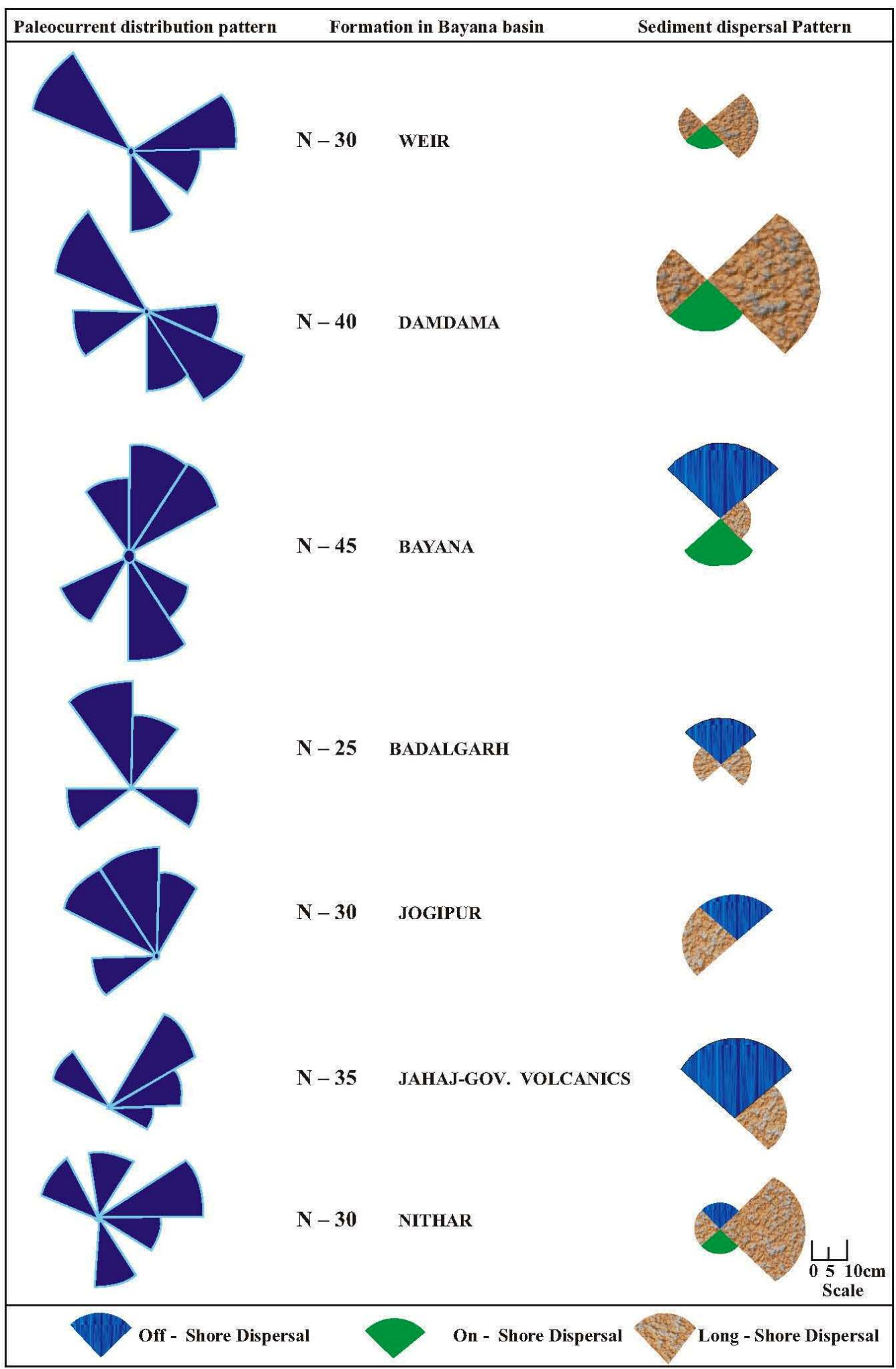

Figure 5. Paleocurrent distribution patterns in different formation of Bayana Basin.

ferent sources during its long depositional history. The sandstone of the Bayana Formation was derived from a source consisting of granotoids and mafic rocks. The
Damdama and Weir sandstones received debris from a source comprising granitoids and TTG in different proportions. The sandstones of the Nithar and Badalgarh 
Formations were probably derived from a granite dominated source terrain [11]. A characteristic of source terraines along the suture zones is a large compositional range of the rocks (e.g. suture zones of Himalaya, Apennines and Pyrenees). However, in the entire suture zone, sandstones in general are more feldspathic than those of deposited in other area [21]. Most of foreland Basin sandstones are fairly uniform in composition [21] reflecting dominance of source rocks that are uplifted and eroded from the thrust sheet and deposited in foreland basin. The large scale compositional variation of the Bayana sandstones reflects the existence of source terrain of a similar to suture zones of Himalaya, Apennines and Pyrenees. Similar types of suture zones are common in Aravalli ñ Delhi foldbelt [22]. The sandstones of the Bayana Basin exhibit large variation in $\mathrm{K}_{2} \mathrm{O} / \mathrm{Na}_{2} \mathrm{O}(0.16$ 10.4) and $\mathrm{Al}_{2} \mathrm{O}_{3} / \mathrm{Ca}+\mathrm{Na}(10-112)$ ratio and their $\mathrm{Fe}_{2} \mathrm{O}_{3}$ $+\mathrm{MgO}$ contents are low $(0.21$ - 11). In general they are enriched in $\mathrm{SiO}_{2}$ and are significantly depleted in $\mathrm{Na}_{2} \mathrm{O}$ and $\mathrm{CaO}$. These are the geochemical characteristics which are generally by sedimentary rocks of passive margins [11].

\section{Conclusions}

a) The Bayana Basin defining eastern most limit of the great Delhi Basin is a fossil graben with over $3000 \mathrm{~m}$ thick metavolcanics and metasedimentary successions. Petrographic studies reveal that grains are medium to fine grained, moderately well sorted, subangular to subrounded and have low sphericity. The framework grains are mostly quartz and least frequently of feldspar, rock fragments and heavy minerals. The composite distribution of cross bedding azimuths aggregated from the study area indicates dispersal of sediments from four different directions, indicating multidirectional clastic transport in offshore, onshore and long shore direction. The source rocks were most probably BGC and Aravalli Supergroup.

b) The depositional processes and environment have been employed to categorize four main genetic lithofacies assemblages. Facies assemblage A represents tidally influenced fluvial deposits. Facies assemble B tidal/intertidal deposits. Facies assemble $\mathrm{C}$ represents tidal channel deposits and facies assemblage $\mathrm{D}$ represents wave and storm dominated shoreface deposits. These contrasting paleoenvironmental setting suggest deposition at a Basin margin, through several episodes of transgression and consecutive regression. Bimodal to quadrimodal distribution pattern of paleocurrent for different Formations of Bayana Basin indicate dispersal of sediment by multidirectional currents in nearshore shallow marine environment.

c) The Qt-F-L diagram which emphasized factors controlled by provenance relief, weathering and transport mechanism is based on total quartzose, feldspar and lithic content. Most of the samples lie in continental block provenance field suggesting contribution from the craton interior with basement uplift. Rest of the samples fall in the recycled orogen provenance which suggest their derivation from metasedimentary and sedimentary rocks that were originally deposited along former passive continental margins. The Qm-F-Lt plot showed that the samples fall in continental block provenance with little contribution from the recycled orogen provenance. In the Qm-P-K diagram, the data lie in the continental block provenance reflecting maturity of sediments and stability of the source area. In Qp-Lv-Ls plot, the sample data mostly fall in mixed orogenic provenance with contribution from arc orogen source and fold thrust belt source. Analysis of data from the plotting of triangular diagram does not exactly suggest the source interpretation which is due to weathering and post-diagenetic modification of the unstable minerals. Considering the analysis of data plotted on different triangular diagram, a tectonic collage can be suggested as tectonic setting. This interpretation is also supported by the evolutionary history of the Bayana Basin.

d) The sandstones are quartzrich, primarily derived from a granite-gneiss terrain of a craton interior as well as minor pre-existing sedimentary sequences. The sandstones of the Nithar and the Badalgarh Formations had their source in a granite dominated source terrain.

\section{Acknowledgements}

The authors gratefully thank the Chairman, Dr. L. A. K. Rao, Reader, Department of Geology, Aligarh Muslim University, Aligarh for providing all necessary research facilities during this work.

\section{REFERENCES}

[1] A. H. M. Ahmad and G. M Bhat, "Petrofacies, Provenance and Diagenesis of the Dhosa Sandstone Member (Chari Formation) at Ler, Kachchh Basin, Western India," Journal of Asian Earth Sciences, Vol. 27, No. 6, 2006, pp. 857-872. doi:10.1016/j.jseaes.2005.08.005

[2] F. L. Schwab, "Sedimentation 'Signatures' of Foreland Basin Assemblage: Real or Counterfeit,” International Association of Sedimentology, Special Publications, Vol. 8, 1986, pp. 395-410.

[3] K. Akhtar and A. H. M. Ahmad, "Single-Cycle Cratonic Quartzarenites Produced by Tropical Weathering: The Nimar Sandstone (Lower Cretaceous), Narmada Basin, India,” Sedimentary Geology, Vol. 71, No. 1-2, 1991, pp. 23-32. doi:10.1016/0037-0738(91)90004-W

[4] M. R. Bhatia, "Rare Earth Element Geochemistry of Australian Paleozoic Greywack and Mud Rocks Provenance and Tectonic Control,” Sedimentary Geology, Vol. 45, No. 1-2, 1985, pp.77-113. 
[5] P. G. Decelles and F. Hertel, "Petrology of Fluvial Sands, from the Amazonian Foreland Basin, Peru and Bolivia," Geological Society of American Bulletin, Vol. 101, No. 12, 1989, pp. 1552-1562.

[6] W. R. Dickinson and C. A. Suczek, "Plate Tectonics and Sandstones Compositions," American Association of Petroleum Geology Bulletin, Vol. 63, No. 12, 1979, pp. 21642182.

[7] W. R. Dickinson and R. Valloni, "Plate Setting and Provenance of Sands in Modern Ocean Basins,” Geology, Vol. 8, No. 2, 1980, pp. 82-86.

doi:10.1130/0091- 7613 (1980) 8<82: PSAPOS>2.0.CO;2

[8] L. J. Suttner, A. Basu and L. M. Mack, "Climate and Origin of Quartzarenites,” Journal Sedimentary Petrology, Vol. 51, No. 4, 1981, pp. 1235-1246.

[9] A. Basu, "Influence of Climate and Relief on Composition of Sand Release at Source Areas,” In: G. G. Zuffa, Ed., Provenance of Arenites Reidel, D. Reidel Publishing Company, Dordrecht, Boston, Lancaster, 1985, pp. 118.

[10] J. H. Grantham and M. A. Velbel, "The Influence of Climate and Topography on Rock Fragment Abundance in Modern Fluvial Sands of the Southern Blue Ridge Mountain, North Carolina,” Journal of Sedimentary Petrology, Vol. 58, No. 2, 1988, pp. 219-227.

[11] G. H. Girty, “A Note on the Composition of Plutoniclastic Sand Produced in Different Climatic Belts: Short Note,” Journal of Sedimentary Petrology, Vol. 61, No. 3, 1991, pp. 428-433.

[12] F. R. Lucchi, "Influence of Transport Processes and Basin Geometry on Sandstone Composition,” In: G. G. Zuffa, Ed., Provenance of Arenites, D. Reidel Publishing Company, Dordrecht, 1985, pp. 19-45.

[13] I. S. Espejo and O. R. L. Gamundi, "Source versus Depositional Controls on Sandstone Composition in a Foreland Basin: The Imperial formation (Mid. CarboniferousLower Permian), San Rafael Basin, western Argentina,” Journal of Sedimentary Research, Vol. 64, No. 1, 1994, pp. 8-16.

[14] E. F. Mcbride, "Diagenetic Processes that Effects Provenance Determination in Sandstones,” In: G. G. Zuffa, Ed.,
Provenance of Arenites Reidel, Dordrecht, Lancaster, 1985, pp. 95-114.

[15] M. Raza, A. H. M. Ahmad, M. S. Khan and F. Khan, "Geochemistry and Detrital Modes of Proterozoic Sedimentary Rocks, Bayana Basin, North Delhi Fold Belt: Implications for Provenance and Source Area Weathering,” International Geology Review, Vol. 54, No. 1, 2010, pp. 111-129.

[16] G. H. Mack, "Exception to the Relationship between Plate Tectonics and Sandstone Composition,” Journal of Sedimentary Petrology, Vol. 54, No. 1, 1984, pp. 212- 220

[17] S. P. Singh, "Paleogeography and Clastic Dispersal of the Proterozoic Delhi Supergroup in the Bayana Sub-Basin, Northeastern India,” Journal of Indian Association Sedimentologist, Vol. 10, No. 2, 1991, pp. 19-36.

[18] S. P. Singh, "Stratigraphy of Delhi Supergroup in the Bayana Sub-Basin, Northeastern Rajasthan,” Record Geological Survey of India, Vol. 112, No. 7, 1982, pp. 45-62.

[19] W. R. Dickinson, "Interpreting Relations from Detrital Modes of Sandstone,” In: G. G. Zuffa, Ed., Provenance of Arenites Reidel, D. Reidel Publishing Company, Dordrecht, Boston, Lancaster, 1985, pp. 333-361.

[20] J. F. Dewey and J. M. Bird, "Plate Tectonic and Geosyn-clines,” Tectonophysics, Vol. 10, No. 5-6, 1970, pp. 625-638. doi:10.1016/0040-1951(70)90050-8

[21] H. A. Wanas and N. M. Abdel-Maguid, "Petrography and Geochemistry of the Cambro-Ordovician Wajid SandStone, Southwest Saudi Arabia,” Asian Journal of Earth Sciences, Vol. 11, No. 4, 2006, pp. 280-295.

[22] R. Cox and D. R. Lowe, "A Conceptual Review of Regional Scale Controls in the Compositions of Continental Blocks and Their Sedimentary Cover," Journal of Sedimentary Research, Vol. 65A, No. 1, 1995, pp. 1-12.

[23] S. N. Gupta, Y. K. Arora, R. K. Mathur, I. B. Prasad, T, N. Sahai and S. B. Sharma, "The Precambrian Geology of the Aravalli region, southern Rajasthan and northeastern Gujra,” Geololgical Survey of India Memoir, 1997, pp. 123-262. 